(C) 2019 Terenko. This article is distributed under the terms of CC Attribution-Share Alike 4.0 Internationalas described at https://creativecommons.org/ licenses/by-sa/4.0

UDC:378.091

DOI: $\underline{10.31499 /}$

\title{
ADULT EDUCATION IN UKRAINE: PROBLEMS AND PERSPECTIVES
}

\author{
Olena Terenko \\ Ph.D. in Education, Associate Professor \\ Sumy State Pedagogical University named after A. S. Makarenko, Sumy, Ukraine \\ ORCID: 0000-0003-1427-921x, e-mail: eterenko@ukr.net
}

The article is devoted to the research of peculiarities of adult education development in Ukraine beginning from the $19^{\text {th }}$ century and ending in the early $21^{\text {st }}$ century. To work out the recommendation for successful functioning of adult education in Ukraine, the author refers to four assumptions: ontology, epistemology, methodology and methods.

At the stage of onthology the author systematized first providers of adult education in Ukraine. Five types of schools for adults functioned at the beginning of the $20^{\text {th }}$ century, namely schools for adults, including Sunday and evening schools, training, which was aimed at overcoming illiteracy, repetitive applications of general courses. Sunday school for adults became not only a place of literacy acquisition but created conditions for the development of the democratic movement, awareness, preservation of national cultural values.

On the epistemological stage, the researcher traced changes in the functions of adult education in different historical periods, as adult education was gradually replaced by political education. At the beginning of the $20^{\text {th }}$ century, we traced broadening of the functions of adult education, for the purpose of education, engaged in adult education was not only literacy but also the exercise of political education.

At the stage of methodology, the author analysed the influence of the inter-national community on the development of adult education at the beginning of the $21^{\text {st }}$ century. Ukrainian Coordinating Unit «Adult Education of Ukraine» operates under the support of UNESCO Institute of Lifelong Learning (UNESCO Institute of Lifelong Learning) and brings together public, private organizations to help adults with low income, especially people of the third age in learning and self-improvement every year since 2000.

At the stage of methods, the recommendations for adult education development in Ukraine, taking into account Canadian and American experience, were worked out, for these are highly developed countries with a system of vast educational opportunities for adults.

Key words: adult education, Ukraine, Sunday school, evening school, repetitive courses, UNESCO Institute of life-long learning, the conception of adult education in Ukraine.

Стаття присвячена дослідженню особливостей розвитку освіти дорослих $b$ Украйні починаючи з ХІХ століття і до початку XXI століття. Для вироблення рекомендацій щодо успішного фуукиіонування осъіти дорос-лих $b$ Украйні автор посилається на чотири припущення: онтологію, епістемологію, методологію та 
методи.

На етапі онтологї автор систематизувала перших провайдерів освіти дорослих в Украйні. На початку XX століття функиіонувало п'ять типіВ шкіл для дорослих, а саме: школи для дорослих, включаючи недільі та вечірні иколи, навчання, спрямоване на подолання неписъменності, повторне засто-сування загальних курсів. Недільна школа для дорослих стала не мише місцем засвоєння грамотності, але й створила умови для розвитку демократичного руху, усвідомлення, збереження національних культурних цінностей.

На епістемологічному етапі дослідниця простежила зміни у функціях освіти дорослих у різні історичні періоди, оскілки освіта дорослих поступово замінювалася політичною освітою. На початку XX століття простежу-валося розширення функцій освіти дорослих, з метою навчання дорослих не миче грамотності, а й елементам політичної освіти.

На етапі методології автор проаналізувала вплив міжнародної спільно-ти на розвиток осВіти дорослих на початку ХХІ століття. Украӥнсъка координаційна група «Освіта дорослих Украӥни» працюе за підтримки Інституту безперервного навчання ЮНЕСКО та об'єднує громадсъкі та приВатні організачї̈, які допомагають дорослим з низъким рівнем доходів, особливо людям третъого Віку $b$ навчанні та самовдосконаленні - покращення щороку з 2000 року.

На етапі методів були розроблені рекомендації щодо розвитку освіти дорослих в Украйні з урахуванням канадсъкого та американсъкого досвіду, для яких це Високорозвинені краӥни з системою великих освітніх можливостей для дорослих.

Ключові слова: освіта дорослих, Украйна, недільна школа, вечірня школа, повторюъані курси, Інститут безперервного навчання ЮНЕСКО, концепџія осВіти дорослих в Украӥні.

Introduction. Social and economic changes taking place in Ukraine and its integration aspirations necessitate reform of the education system, acknowledging its key role in social change. Adult education is an important component of the national education system, scientific and technological imperative, and a means of over-coming the global economiccrisis, the crisis of competence.

Careful analysis of research in adult education in developed countries, in particular, in Canada and in the USA proves that the experience of adult education in these countries may be helpful in reforming adult education in Ukraine. This idea is reinforced by the fact that Ukraine seeks to improve its own educational system in accordance with international standards and declares its commitment be among developed democratic countries in Europe.

For successful implementation of progressive foreign experience for im-proving the system of adult education in Ukraine, we need to adhere to four stages in our research work. At the stage of ontology, we should systematize providers of adult education that existed in Ukraine beginning from the $21^{\text {st }}$ century. At the stage of epistemology, it is necessary to classify functions of adult education in Ukraine. At the stage of methodology, it is necessary to analyse peculiarities of adult education development at the beginning of the $21^{\text {st }}$ century in Ukraine. At the stage of methods, we can work out the recommendations for successful implementation of Canadian and American experience of adult education in Ukraine at the beginning of the $21^{\text {st }}$ century.

At the stage of ontology, we need to classify providers of adult education in Ukraine, which existed beginning from the 19th century. The study proves that there is a positive experience of adult education in Ukraine. Ukrainian education was one of the first in developing of andragogy. In the second half of the $19^{\text {th }}-$ early $20^{\text {th }}$ - century active research 
work was conducted by C. Alchevska and was aimed at developing didactic and methodological principles of adult education in Sunday schools. Created under the direction of C. Alchevska, joint efforts of teachers of Kharkiv Sunday schools, scientists and specialists of different fields of knowledge «Book for adults» was the first in the history of public education guide compiling specific for adult education. For over two decades, this book was reprinted almost every year, it was used not only in Sunday school and Sundayevening classes of workers, but also in many other educational institutions of Ukraine, as well as in public libraries and reading rooms at different courses. The theory of educational activities for adults was developed in the $20^{\text {th }}$ century. The director of the native school gymnasium in Rohatyn, founder of the Peasant University for adults, M. Haluschynskyi due to his organizational work, propaganda, scientific papers and studios became the first Ukrainian specialist in andragogy. Before the war, adult education in Ukraine was represented by a popular movement for the elimination of illiteracy using circles, groups of huts-reading rooms, libraries.

Sunday school for adults became not only a place of literacy acquisition, but it created conditions for the development of the democratic movement, awareness, preservation of national cultural values. Therefore, they closed all Sunday schools in 1862, as well as people's reading rooms and public lectures, the prohibition was a significant blow to adult education, to the formation of democratic views of people on life development. Only in 1871, it was allowed to open schools and the Sunday courses for adults.

Further development of adult education in the late 19th - early 20th centuries had democratic ideas. Evening schools, Sunday schools for adults, as well as Lecture Bureaus were opened and took care of holding public lectures. One can distinguish five types of schools for adults functioning at the beginning of the 20th century, namely schools for adults, including Sunday and evening schools, training which was aimed at overcoming illiteracy; repetitive applications of general courses. The duration of the courses was three years,and their main purpose was to provide secondary education for those who did not receive it on time. Their goal was to provide people with more knowledge of the initial level of education that combines schooling with work.

More systematic development of the theory and practice of adult education in Ukraine began after 1917 when all the power was thrown into the fight against illiteracy. It was created by the Institute of adult education, which took care of teacher training and research work on the problems of adult education are covered in the pages of the newly established magazine «School education».

In the public policy of the 20 years of the XX century struggle against illiteracy was one of its priorities as state aid implemented extensive adult education and cultural development of the people, began its institutionalization. Note that one of the first decrees of the Soviet government was a decree «On the elimination of illiteracy among the population» (1919), in which every citizen aged 8 to 50 years had to learn to read. The primary responsibility for carrying out the provisions of the decree was assigned to the newly created voluntary society «Down with Illiteracy» (1923), with the slogan - «Literate! You have to teach illiterate». The society organi-zed conferences, congresses, seminars on adult education. However, adult education was gradually replaced by political education. It was seen as political and educa-tional activities, and the purpose of education, engaged in adult education was not only literacy but also the exercise of political education. The system combines adult education such as institutions, educational program, literate high school type [16].

At the stage of epistemology, we need to trace changes in functions of adult education which occurred in the $20^{\text {th }}$ century comparing them with functions that were in the 19th century. The analysis of scientific sources shows that the develop-ment of adult education 
in the postwar years, was explained by political and economic realities of the $50^{\mathrm{s}}$ of the $20^{\text {th }}$ century, common goals, standing before education: the revival of education, rehabilitation and construction of educational institutions, combating illiteracy among adults. Therefore, the main function of adult education is compensatory, that point to compensate deficiencies in education. However, adaptation remained an important feature that has intensified training for various industries. The political and educational function of adult education remained one of the top priorities. There was an active formation of networks of educational institutions and various forms of adult education.

People's universities played an important educational role in the $20^{\text {th }}$ century. There was quite a wide network of people's universities: in 1961 their number was 6357, and their audience was $1 \mathrm{mln}$. 598 thousand. Their benefits are access to free training in democratic governance and communication, consideration of the educational needs of students of all ages. Some of them could be called, by analogy with the present name, the University of the Third Age, as many retired people visited them. But, unfortunately, gradually intensified the ideological orientation of their activities, and in the 1990s people's universities ceased their existence [18].

Post-war recovery system of adult education caused an increase in the number of schools for working and rural youth, which in 1958 was reorganized into secondary schools for adults. The common form of adult education in the 1970s was lecture that popularized knowledge actively and helped to form a network of graduate schools, institutes and universities for training and retraining. The deterio-ration of the socio-economic situation in the years of independence destroyed the Soviet fairly coherent system of adult education, drastically reduced the number of evening schools and people's universities, almost stopped government funding in this area.

At the stage of methodology we need to single out peculiarities of adult edu-cation development at the beginning of the XXI century. Development of a market economy in the 90-s of the XX century was a real test for many people, due to the loss of the specialty, unnecessary labour market confusion and misunderstanding that once obtained education does not meet requirements of the labour market and so on. The adult education system was completely destroyed. It was necessary to look for new ways to play according to socioeconomic changes taking place in society.

90 years of the XX century are characterized by the following trends in the development of adult education such as preservation and attachment of institutions training and retraining, which appeared in Soviet times to the new realities of life; the emergence of centers, departments in universities, offering adult education ser-vices on a commercial basis; sharp decline in educational activities; the emergence of non-state (private and public) institutions and organizations, offering diverse educational programs for adults.

Until now there is no law on adult education, while in 2004 such an attempt was made. Unfortunately, the initiative was not supported in the Verkhovna Rada and the work on it was suspended. However, the teaching community does everything in order to create conditions for the realization of the need of the law.

We consider necessary to refer to the activities of the Association «Knowledge» - one of the public scientific and educational organizations, which began its existence in 1948 as the Society for the dissemination of political and scientific knowledge and still has a significant impact on the development of non-formal adult education in Ukraine. Since 1999, V. Kremen is a president of the Society «Knowledge». Today the Society «Knowledge» is working to create a knowledge base of information, and in plans - building a corporate information network [17].

It is necessary to highlight the fact that in Ukraine the first High School was opened 
in 1959 in Sevastopol. Today high schools are working in Kiev, Kirovograd, Lviv, Kremenchuk, Dnipropetrovsk, Poltava, Kharkiv and other cities, offering educational services to adults of all ages. The basis of such schools is voluntary, active, democracy. The curriculum is based on the interests and needs of adult students. Students study the art of singing, local history, language and literature, computer and recovery techniques and more. The most important value is the high school friendly atmosphere, mutual support and mutual respect.

Another form of non-formal adult education, which is used in Ukraine is educational circles. Study groups are the hallmark of the Swedish system of non-formal adult education. Their founder, the «father of training groups for adults» the Swedish educator and scientist A. Olson, in 1902 opened enrollment to the first academic circle [15]. Nowadays academic circles, as a form of non-formal adult education, are widely used in the global educational space. Subject educational groups are chosen by adults taking into account interests and educational needs. For example, thanks to the project of the Poltava regional branch of the League of Social Workers of Ukraine «Training workshop for adults - education for all», Ukrainians invited adults to work in educational circles «World of camera lens».

An important achievement in the development of non-formal adult education in Ukraine was opening Universities of the Third Age. The first University of the Third Age was established in Kovel in Volyn, in particular, Kovel territorial centre of social and domestic rehabilitation. The learning process at the university is defined by desires and interests. Today Ukraine, according to the Ministry of Social Policy, has more than 300 Universities of the Third Age, particularly in Kiev, Kharkov, Lvov, Ternopol, Nikolaev, Zhitomir, Shostka, Cherkasy, Uman, Sumy, Kirovograd and other cities of Ukraine. More than 25 thousand people elderly study at the universities of the third age. For example, Kyiv Third Age University has seven faculties: psychology, law, choral singing, healthy lifestyle, literature and art department. Its students are not only involved in different forms of learning (lectures, discussions, debates, watching movies, etc.) but also go on excursions, visit theatres, exhibitions, concerts and even participate in theatre «Retro Grandma» and the amateur team «Kyyanochky first!» [19].

The University of the third age, higher public school, an academic circle can be considered as specific components of the national system of informal adult education, and the best examples of implementing the ideas of the world experience of adult education.

Communities in Ukraine still not fully realize their potential for the develop-ment of non-formal adult education. Although some successful projects already exist. An example is the project «Think democratically». Human rights in training programs were initiated by the Foundation «Resonance» (Lviv), social and educa-tional society «Edukator» (Lomza, Poland). The project analyzed the curriculum in terms of human rights issues.

The educational community establishes cooperation with the Institute for International Cooperation of the German Association of People's Universities (DVV International), which collaborates with more than 1000 higher national schools and national universities in 40 countries. With the support of DVV many projects in non-formal adult education were implemented in Ukraine, including «Development of a network of rural centers of adult education in this district», «Expanding the network service center», «Methodological platform andragog-Practice», «Support to vulne-rable populations in Western Ukraine during the crisis», «Professional education and resocialization» and others.

Nowadays providers of formal adult education in Ukraine are mainly public establishments that specialize in retraining and advanced training of specialists of every sector; informal adult education is often provided by public non-profitable organizations that develop and apply training programs in various educational projects. The trainers are 
prepared to implement these educational programs, publish educational materials. In particular, they are:

- public organization «Knowledge», which publishes books and has opened «University of Modern Knowledge»;

- Society «Enlightenment», which also publishes books and receives little government subsidies;

- Ukrainian Coordinating Unit «Adult Education of Ukraine», which operates under support of UNESCO Institute of Lifelong Learning (UNESCO Institute of Lifelong Learning) and brings together public, private organizations to help adults with low income, especially people of the third age in learning and self-improvement every year since 2000, conducts nationwide «Week of adult education», evaluates the quality of adult education and awards andragogy who managed to provide the best quality of adult learning.

A significant step towards a national conception of adult education was the adoption of «Conception of distance education in Ukraine» in December 2000. L. Lukyanova and a group of scientists from the Institute of Pedagogical Education and Adult Education of NAPS Ukraine developed «Conception of adult education in Ukraine (2009) and presented conceptual provisions of adult education in Ukraine [14]. In terms of economic restructuring and transition of Ukraine to market conditions, it is crucial to form the ability and willingness of our population to adapt to new and unexpected situations. Adult education should take into account the specifics of national history, culture and Ukrainian mentality, which was formed during long period.

At the stage of methods to improve the national system of adult education it is necessary to take into account foreign experience, in particular, American and Canadian, and

- to create a legal framework for adult education, adopt legislative and regulating acts, special laws or relevant parts of the common law on education, which would define: the concept, features, objectives and priorities of adult edu-cation; status category of adult learners; the composition of the content of adult education; ways of funding (state government assistance, grants and attracting businesses, employment services and other additional financial resources); rights and obligations of participants in the learning process; institutionalize adult education and leadership as an independent field of education in general, as the lack of legislation leads to unsystematic research and the absence of organizational structure of adult education;

- to intensify the priority of development of theoretical, methodological, technological and scientific foundations of lifelong learning, based on psychology of an adult, because technological problems of adult education reduces the effectiveness of teaching students; create conditions for the participation of social movements in the development of ways to organize adult education;

- to ensure close and effective communication between the institutions invol-ved in adult education and labour market, as the adult education system should focus on the real needs of customers;

- to develop a conceptual basis of flexible, multi-level, diversified structure of adult education; develop national and regional strategies of adult education; conduct a national study of adult education in Ukraine in order to obtain specific statistics on the participation of students in adult education projects according to their age, gender, family and social status, presence/absence of previously obtained education; the level of functional literacy etc; 
- to include speciality «Andragogy» in the list of specialities of postgraduate professional education;

- to establish a system of training, regular retraining and professional development of adult educators through special training courses, training abroad etc.;

- promote and encourage adults to master new skills for adaptation to changing and complex conditions of life by introducing tax breaks, financial, social and other incentives;

- to develop basic parameters of the organizational structure of adult education, using an extensive network of schools and educational departments of different forms (governmental, public and private);

- to improve the network of distance learning for adults because it provides an open, unlimited, mass, public and continuous nature of vocational education; intensify enlightenment activities aimed at improving the overall cultural and social activity of the population, the preservation of national characteristics;

- to recognize informal adult education as an integral part of lifelong education, to expand and improve the organization of informal adult education in everyday conditions of employment, occupational activity (corporate training), during leisure or vacation, since it directly reflects the non-formal education and meets personal needs and requests of individuals mobilizing one's natural ability to self-improvement and spiritual inner growth;

- to enable validation and certification of the results of previous adult education, recognition of which significantly improves freedom of rights in building up individual educational trajectory, increases educational motivation, improves the processes of formation and professional development of qualified personnel;

- to develop a special program of educational services for people who do not speak the national language;

- to regularly take measures for the promotion of lifelong education, cultivate rights;

- to develop a system of marketing (information and orientation in public education services) and information consultancy (database development, modern equipment information flows, the use of computer technology), support educational services for adults;

- to implement a partnership strategy with adult education issues at the international level as the coordination strategy of Ukraine in the field of lifelong learning and development of a national system of adult education corresponding the global strategy of adult education as it will contribute to the development of the national organization of adult education.

So, the primary purpose is providing professional and personal development of adults throughout life, according to the needs of individuals, economy and society. However, at the present stage of non-formal adult education in Ukraine, there are many challenges and problems, and the solution to them can be found by analyzing, systematizing and adapting the experience of countries that have some achievements in the development of non-formal adult education, including the United States and Canada.

Conclusions. Our research has already passed three stages. At the stage of ontology, we systematized first providers of adult education in Ukraine. Five types of schools for adults that functioned at the beginning of the 20th century, namely schools for adults, including Sunday and evening schools, training in which was aimed at overcoming illiteracy. Sunday schools for adults became not only a place of literacy acquisition, but they created conditions for the development of the demo-cratic movement, awareness, preservation of national cultural values.

At the epistemological stage, we traced changes in the functions of adult education in different historical periods, as adult education was gradually replaced by political education. At the beginning of the $20^{\text {th }}$ century, we analyzed broadening of the functions of adult education. 
At the stage of methodology, we investigated the influence of the international community on the development of adult education at the beginning of the $21^{\text {st }}$ century. Ukrainian Coordinating Unit «Adult Education of Ukraine» operates under the support of UNESCO Institute of Lifelong Learning (UNESCO Institute of Lifelong Learning) and brings together public, private organizations to help adults with low income, especially people of the third age in learning and self-improvement every year since 2000.

At the stage of methods, we worked out the recommendations for adult education development in Ukraine, taking into account Canadian and American experience, for these are highly developed countries with a system of different educational opportunities for adults.

\section{References:}

1. Apps, J. (2009). Providers of adult and continuing education framework. San Francisco: Jossey-Bass.

2. Bergevin, P. (2007). Philosophy for Adult Education. New York: Seabury.

3. Cambridge Center for Adult Education. Available at: $h t t p: / / w w w . c c a e . o r g / i n d e x . h t m l$

4. Dave, R. (2006). Foundations of Lifelong Education. Hamburg: UNESCO Institute for Education: Pergamon Press.

5. European guidelines for validating non-formal and informal learning (2009). Luxembourg: Office for Official Publications of the European Communities.

6. Hesburgh, T. (2003). Patterns for Lifelong Learning. NY: Jossey-Bass.

7. Hopkins, N. (2014). Citizenship and democracy in further and adult education.Dordrecht: Springer.

8. Jarvis, P. (2012). Adult Learning in the Social Context.London: Routledge.

9. Kidd, T. (2010). Online education and adult learning: new frontiers for teaching practices. $1^{\text {st }}$ ed. Hershey, P. A: Information Science Reference.

10. Lamb, R. (2012). Participation in Lifelong Learning Institutes: What Turns Members On? Portland, Maine: Osher Lifelong Learning Institute University.

11. Merriam, S. (2013). Adult Learning: Linking Theory and Practice. Sharan San Francisco: Jossey-Bass.

12. National Institute for Literacy Available at: http://www.nifl.gov/nifl/facts/reading_facts.html.

13. Pandya, R. (2010). Adult and non-formal education.New Delhi: Gyan Pub. House.

14. Лукянова, Л. Б. (2011). / Концепиія освіти дорослих в Україні. Ніжин: ПП Лисенко М. М.

15. Огієнко, О. I. (2008). Тенденції розвитку освіти дорослих у Скандинавських країнах. Суми: Елада-S.

16. Теренко, О. (2018). Організаційно-змістові аспекти діяльності провайдерів освіти дорослих у США $i$ Канаді. Неперевна професійна освіта: теорія і практика, № 3, 11-115.

17. Товариство «Знання» України. // [Електронний ресурс] - Режим доступу: http/znаппуа.org.uа.

18. Університет третього Віку у КиєВі. // [Електронний ресурс] - Режим доступу: http://Зvik. peredusim.kiev.ua/about-us.

19. Університет третього віку при Дніпропетровському університеті імені Альфреда Нобеля. // [Електронний ресурс] - Режим доступу: http://duep.edu/uk/third_age_univercity_group/ university_of_the_third_age.

20. Центри Освіти Дорослих Освіта як суспільна відповідальність. (2011). Берлін: DVV. 